\title{
Monetary Policy under Neoclassical and New-Keynesian Phillips Curves, with an Application to Price Level and Inflation Targeting
}

\author{
Michael T. Kiley* \\ May 20, 1998
}

*Address: Division of Research and Statistics, Federal Reserve Board, Washington, DC 20551, phone: (202)452-2448, e-mail: mkiley@ frb.gov. I would like to thank Adam Posen, workshop participants at the Federal Reserve Board and the Federal Reserve System Committee Meeting on Macroeconomics at the Federal Reserve Bank of New York, and especially Lars Svensson for comments on an earlier paper on this subject. The views expressed herein are solely the author's, and do not reflect those of the Federal Reserve Board or its staff. 


\title{
Monetary Policy under Neoclassical and New-Keynesian Phillips Curves, with an Application to Price Level and Inflation Targeting
}

\begin{abstract}
This paper compares discretionary monetary policy under two Phillips curves. Previous work uses a Phillips curve consistent with "Neoclassical" models of price adjustment. Sticky price models imply a "New-Keynesian" Phillips curve based on staggered price setting that delivers familiar results on an inflationary bias and inflation contracts. However, the comparison of price level and inflation targeting reveals an output/price stability tradeoff under the New-Keynesian model that does not arise under the Neoclassical specification, illustrating the usefulness of considering the New-Keynesian model. Given the empirical support for the New-Keynesian specification, a stability tradeoff likely exists.
\end{abstract}

JEL Codes: E52, E31, E58

keywords: time-inconsistency, rules, base drift 
The literature on monetary policy decisions in an economy characterized by a Phillips curve, rational expectations, and time-inconsistency has addressed questions regarding the inflationary bias under discretionary monetary policy (Barro and Gordon (1983)), the design of monetary institutions (Rogoff (1985), Schaling (1995), and Walsh (1995)), political business cycles (Alesina (1987)), and the debate over inflation and price level targeting (Svensson (1996)). Standard models of this type use a "Neoclassical" Phillips curve to discuss the above issues. This paper considers an alternative "New-Keynesian" Phillips curve in a standard time-inconsistency framework. The standard results on an inflationary bias, the implications of "conservative" central bankers, and the effectiveness of linear inflation contracts in ameliorating the inflationary bias, readily fall out of the model based on the NewKeynesian Phillips curve. However, a comparison of inflation and price level targeting under the New-Keynesian Phillips curve implies that assigning a price level target to the central bank increases expected output fluctuations relative to expected output fluctuations under inflation targeting. The increase in expected output fluctuations under price level targeting in a New-Keynesian Phillips curve model contradicts Svensson's (1996) claim (derived in a Neoclassical Phillips curve model) that price level targeting is a "free lunch", and illustrates the usefulness of using New-Keynesian Phillips curves rather than Neoclassical Phillips curves for policy discussions.

The analysis of price level and inflation targeting under the New-Keynesian Phillips curve identifies the source of disagreement between Svensson's (1996) analytical results on assigning central banks inflation or price level targets, and a growing conventional wisdom on the implications of price level targeting. The conventional wisdom from simulations of small 
scale "Keynesian" macroeconomic models under inflation and price level targeting is that price level targeting raises output variability because inflationary mistakes must be reversed in order to prevent base drift in the price level, and the reversal of inflationary mistakes leads to extra output variability. ${ }^{1}$ For example, Lebow, Roberts, and Stockton (1992) and Fillion and Tetlow (1994) find increases in output fluctuations under price level targeting in simulations of models with price adjustment specifications that imply a New-Keynesian Phillips curve, and this paper demonstrates analytically that the conventional wisdom from model simulations falls cleanly out of the basic New-Keynesian Phillips curve. A Neoclassical Phillips curve does not share the intuition because it does not have gradual price adjustment - as discussed in the model descriptions in section 1.

Section 2 then quickly demonstrates that the standard results on an inflationary bias, "conservative" central bankers, and inflation contracts for central bankers follow from both the Neoclassical model and the New-Keynesian model. Section 3 illustrates that the type of Phillips curve used for analysis is important by demonstrating the different implications of each type for price level and inflation targeting.

\section{The Phillips Curve}

Typical motivations for Phillips curve relations fall into either the Neoclassical or New-Keynesian categories.

\subsection{Neoclassical Phillips Curve Models}

One popular class of models assumes that inflation consists of a component driven by

\footnotetext{
${ }^{1}$ Prominent examples include Lebow, Roberts, and Stockton (1992), Fillion and Tetlow (1994), Fischer (1994), and Haldane and Salmon (1995).
} 
inflation in the flexible price equilibrium price level, and a component based on the lagged expectation of inflation in the flexible price equilibrium price level:

$$
\mathrm{p}_{\mathrm{t}}-\mathrm{p}_{\mathrm{t}-1}=\alpha\left(\mathrm{p}_{\mathrm{t}}^{\text {flex }}-\mathrm{p}_{\mathrm{t}-1}\right)+(1-\alpha) \mathrm{E}_{\mathrm{t}-1}\left(\mathrm{p}_{\mathrm{t}}^{\text {flex }}-\mathrm{p}_{\mathrm{t}-1}\right)-\mathrm{v}_{\mathrm{t}}
$$

where $\mathrm{p}_{\mathrm{t}}$ is the (log) price level, $\mathrm{p}_{\mathrm{t}}^{\text {flex }}$ is the flexible price equilibrium (log) price level (or the long-run desired price level), $\mathrm{E}$ is the expectations operator, $\mathrm{v}_{\mathrm{t}}$ is an inflationary supply shock, and $0<\alpha<1$. The inflation supply shock (v) lends a stochastic element to inflation, as suggested by McCallum (1994, p. 254). Several motivations for inflation specifications like (1.1) are possible. In one class, some fraction of prices (or wages) for period t are set at time t-1 (i.e., one period predetermined prices), and the fraction $\alpha$ can be viewed as the fraction of firms who set their period $\mathrm{t}$ price based on period $\mathrm{t}$ information, with the remaining fraction setting their price at time $\mathrm{t}$ based on lagged information. Work by Barro and Grossman (1976), Fischer (1977), Mussa (1981a, 1981b), McCallum (1994), and Svensson (1996) loosely follows this interpretation. Another popular alternative based on signal extraction stems from Lucas (1973). One key aspect of (1.1) is that all anticipated movements in the flexible price equilibrium price are fully incorporated into inflation. Also, price adjustment is not gradual, as the lagged price level drops out of (1.1).

To generate a Phillips curve relating output to inflation, assume that aggregate supply $\left(y^{s}\right)$ is determined by an exogenous productivity process $(x)$, and aggregate demand $\left(\mathrm{y}^{\mathrm{d}}\right)$ is given by the quantity equation:

$$
\begin{aligned}
& y_{t}^{s}=x_{t}, \\
& y_{t}^{d}=m_{t}-p_{t} .
\end{aligned}
$$

In a flexible price equilibrium, output is determined by aggregate supply (1.2), and $\mathrm{p}_{\mathrm{t}}^{\text {flex }}=\mathrm{m}_{\mathrm{t}}$ - 
$\mathrm{X}_{\mathrm{t}}$. When prices follow (1.1) and output is demand determined, (1.1)-(1.3) imply that output is given by

$$
\mathrm{y}_{\mathrm{t}}=(1-\alpha)\left(\mathrm{m}_{\mathrm{t}}-\mathrm{E}_{\mathrm{t}-1} \mathrm{~m}_{\mathrm{t}}\right)+\alpha \mathrm{x}_{\mathrm{t}}+(1-\alpha) \mathrm{E}_{\mathrm{t}-1} \mathrm{x}_{\mathrm{t}}+\mathrm{v}_{\mathrm{t}}
$$

Taking expectations as of $\mathrm{t}-1$ of (1.1) and subtracting from (1.1) yields

$$
p_{t}-E_{t-1} p_{t}=\alpha\left(m_{t}-E_{t-1} m_{t}-x_{t}+E_{t-1} x_{t}\right)
$$

Inserting (1.5) into (1.4) yields the Phillips curve

$$
\begin{aligned}
& \mathrm{y}_{\mathrm{t}}=\mathrm{a}\left(\mathrm{p}_{\mathrm{t}}-\mathrm{E}_{\mathrm{t}-1} \mathrm{p}_{\mathrm{t}}\right)+\mathrm{x}_{\mathrm{t}}+\mathrm{v}_{\mathrm{t}} / \alpha \\
& \mathrm{y}_{\mathrm{t}}=\mathrm{a}\left(\Delta \mathrm{p}_{\mathrm{t}}-\mathrm{E}_{\mathrm{t}-1} \Delta \mathrm{p}_{\mathrm{t}}\right)+\mathrm{e}_{\mathrm{t}}, \\
& \mathrm{e}_{\mathrm{t}}=\mathrm{x}_{\mathrm{t}}+\mathrm{v}_{\mathrm{t}} / \alpha, \mathrm{a}=(1-\alpha) / \alpha .
\end{aligned}
$$

The expectations augmented Phillips curve in (1.6) is the typical specification that arises in the models discussed above. McCallum (1994) denotes these "Neoclassical" models because they embody the idea that only unanticipated inflation results in output fluctuations, and satisfy the Lucas (1973) definition of the natural rate hypothesis, which requires that no systematic, expected inflation policy can maintain output permanently away from its natural rate.

\subsection{New-Keynesian Phillips Curves}

The class of New-Keynesian Phillips curves models (as denoted by Roberts (1995)) relies on sticky price specifications in which price setters stagger the intervals over which their prices are rigid (Taylor (1980), Calvo (1983)), or on partial adjustment models (Rotemberg $(1982,1987,1996))$. I will derive the Phillips curve implied by the Calvo 
staggered price setting model. ${ }^{2}$

In the Calvo (1983) model, individual firms adjust prices infrequently. In a given period, the probability that any individual firm adjusts its price is constant and equals $\alpha$. The dynamics of the aggregate price level and individual firm prices are given by:

$$
\begin{aligned}
& \mathrm{p}_{\mathrm{t}}=(1-\alpha) \mathrm{p}_{\mathrm{t}-1}+\alpha \mathrm{z}_{\mathrm{t}}-\mathrm{v}_{\mathrm{t}} \\
& \mathrm{z}_{\mathrm{t}}=\alpha \mathrm{p}_{\mathrm{t}}^{\text {flex }}+(1-\alpha) \mathrm{E}_{\mathrm{t}} \mathrm{z}_{\mathrm{t}+1}
\end{aligned}
$$

where $p_{t}$ is the $(\log )$ price level, $z_{t}$ is the price chosen by firms at time $t, p_{t}^{\text {flex }}$ is the flexible price equilibrium (log) price level (or the long-run desired price level), $\mathrm{v}_{\mathrm{t}}$ is an inflationary supply shock, and $0<\alpha<1$. Notice that the price level adjusts gradually, as indicated by the lagged price level on the right hand side of (1.7).

Under the same aggregate demand and potential output assumptions as in the previous section (1.2 and 1.3), $\mathrm{p}_{\mathrm{t}}^{\text {flex }}=\mathrm{m}_{\mathrm{t}}-\mathrm{x}_{\mathrm{t}}$. Equation (1.7) implies

$$
\mathrm{E}_{\mathrm{t}} \Delta \mathrm{p}_{\mathrm{t}+1}=(1-\alpha) \Delta \mathrm{p}_{\mathrm{t}}+\alpha \mathrm{E}_{\mathrm{t}} \Delta \mathrm{z}_{\mathrm{t}+1}
$$

and (1.7) and (1.8) imply

$$
\mathrm{E}_{\mathrm{t}} \Delta \mathrm{z}_{\mathrm{t}+1}=\mathrm{E}_{\mathrm{t}} \Delta \mathrm{p}_{\mathrm{t}+1}+\alpha\left(\mathrm{p}_{\mathrm{t}}-\mathrm{m}_{\mathrm{t}}+\mathrm{x}_{\mathrm{t}}\right)
$$

Combining (1.7), (1.9), (1.10), and (1.3) yields the New-Keynesian Phillips curve

$$
\begin{aligned}
& \mathrm{y}_{\mathrm{t}}=\mathrm{a}\left(\Delta \mathrm{p}_{\mathrm{t}}-\mathrm{E}_{\mathrm{t}} \Delta \mathrm{p}_{\mathrm{t}+1}\right)+\mathrm{e}_{\mathrm{t}}, \\
& \mathrm{e}_{\mathrm{t}}=\mathrm{x}_{\mathrm{t}}+\mathrm{v}_{\mathrm{t}} / \alpha^{2}, \mathrm{a}=(1-\alpha) / \alpha^{2},
\end{aligned}
$$

which resembles the Neoclassical Phillips curve, but differs in a fundamental way.

In particular, the sticky price models which yield a New-Keynesian Phillips curve

\footnotetext{
${ }^{2}$ It is well known from Rotemberg (1987) that the Calvo model and partial adjustment imply the same relationship between prices and output; Roberts (1995) demonstrates that Taylor-style staggered prices generate a Phillips curve similar to that of the Calvo model. Since the Calvo model is the simplest, I present it as the base New-Keynesian Phillips curve model.
} 
imply that it is the deviation of today's inflation from expected future inflation that cause output fluctuations, so that an anticipated future inflation depresses current output. The intuition for this effect is simple, and plausible: when prices are sticky for several periods, firms raise current prices in response to an anticipated future aggregate demand expansion (because price adjustment is infrequent, future changes in desired prices affect the price chosen today). The increase in prices corresponds to a negative shift in aggregate supply, which depresses current output. Section 3 will demonstrate that this impact of anticipated price movements on output in the New-Keynesian framework is very important for consideration of price level targeting.

Before comparing the implications of each Phillips curve for monetary policy, some comments regarding the empirical plausibility of each Phillips curve is in order. The literature suggests that the New-Keynesian model betters captures salient features of the data. For example, Blanchard's (1990) review of the literature indicates that the data suggest important effects of anticipated monetary shocks on output, in line with the New-Keynesian motivations for the Phillips curve, and directly contradicting the essence of the Neoclassical Phillips curve. Also, most small scale, rational expectations macroeconomic models designed for policy analysis incorporate staggered price setting along the lines suggested by Taylor (1980), or some convex price adjustment specification following Rotemberg (1982), in order to adequately describe the data; for example, Brayton and Tinsley (1996) discuss how the new Federal Reserve Board model relies on convex price adjustment costs and rational expectations to generate slow, forward looking price adjustment to describe U.S. inflation.

\section{The Standard Monetary Policy Game Results}


The standard model of discretionary monetary policy assumes that the monetary authority is directed to minimize a loss function (L) which is quadratic in the deviations of inflation and output from their target levels $(\pi$ and $\Upsilon)$ :

$$
\mathrm{L}=\sum_{\mathrm{i} \geq 0} \beta^{\mathrm{i}} \mathrm{E}_{\mathrm{t}}\left\{\left(\Delta \mathrm{p}_{\mathrm{t}+\mathrm{i}}-\pi\right)^{2}+\mathrm{w}\left(\mathrm{y}_{\mathrm{t}+\mathrm{i}}-\Upsilon\right)^{2}\right\}
$$

where $\mathrm{w}$ is the weight placed on output stabilization, and $\beta$ is the discount factor. The output target is assumed to lie above the natural rate of output $(\Upsilon>0)$ due to market distortions.

The monetary authority's minimization of (2.1) involves contemporaneous reactions of inflation to the aggregate supply shocks (e), which I assume are distributed independently over time. In the Neoclassical specification, the public's inflationary expectations are formed before the realization of time $\mathrm{t}$ shocks (i.e., at $\mathrm{t}-1$ ), but the New-Keynesian specification implies that expectations are formed based on period $t$ information. I focus on the discretionary equilibrium to the monetary policy game where the monetary authority cannot commit, and therefore takes expectations as given when choosing inflation.

Minimizing (2.1) with respect to inflation, subject to either the Neoclassical (1.6) or New-Keynesian (1.11) Phillips curves, yields the first order condition

$$
\Delta \mathrm{p}_{\mathrm{t}}-\pi=-\mathrm{aw}\left(\mathrm{y}_{\mathrm{t}}-\Upsilon\right)^{3}
$$

Guessing that the inflation solution involves a constant and the inflationary shock under both Phillips curves, and substituting (1.6) or (1.11) into (2.2) yields the solution for discretionary monetary policy under each Phillips curve:

Neoclassical: $\quad \Delta \mathrm{p}_{\mathrm{t}}=\pi+\mathrm{aw} \Upsilon-\left(\mathrm{aw} /\left(1+\mathrm{a}^{2} \mathrm{w}\right)\right) \mathrm{e}_{\mathrm{t}}$

\footnotetext{
${ }^{3}$ Note that this first order condition uses the inability of the monetary authority to commit in that current actions have no effect on future expected inflation (under both Phillips curves), making maximization of (2.1) essentially static.
} 
New-Keynesian: $\quad \Delta \mathrm{p}_{\mathrm{t}}=\pi+\mathrm{aw} \Upsilon-\left(\mathrm{aw} /\left(1+\mathrm{a}^{2} \mathrm{w}\right)\right) \mathrm{e}_{\mathrm{t}}$

Under both types of Phillips curves, the discretionary monetary policy is identical, and contains an inflationary bias which results in higher than average desired inflation, and no benefit in terms of better average output performance. This inflationary bias results because the monetary authority cannot credibly commit not to exploit the Phillips curve when the monetary authority places a positive weight on output stabilization $(\mathrm{w}>0)$.

The similarity of monetary policy under both Phillips curves reveals that most of the popular results in the time-inconsistency literature on monetary policy derived with Neoclassical Phillips curves can be derived with the New-Keynesian Phillips curve. For example, Rogoff (1985) demonstrates that "conservative" central bankers can alleviate the inflationary bias, at the cost of greater output variability, in a Neoclassical Phillips curve model. The same result, corresponding to appointing a central banker with a low w in (2.3), occurs in the New-Keynesian model.

Another recently popular line of work develops linear inflation contracts for central bankers that alleviate the inflationary bias by imposing a penalty on the central bank for exceeding its inflation target $\pi$ (Walsh (1995)). This device has gained popularity because of New Zealand's central bank reforms, which incorporate penalties for inflation deviations from target. Following Svensson (1997), the linear inflation contract can be viewed as augmenting the central bank's loss function (2.1) with a penalty,

$$
\mathrm{L}=\sum_{\mathrm{i} \geq 0} \beta^{\mathrm{i}} \mathrm{E}_{\mathrm{t}}\left\{\left(\Delta \mathrm{p}_{\mathrm{t}+\mathrm{i}}-\pi\right)^{2}+\mathrm{w}\left(\mathrm{y}_{\mathrm{t}+\mathrm{i}}-\Upsilon\right)^{2}+\mathrm{f}\left(\Delta \mathrm{p}_{\mathrm{t}+\mathrm{i}}-\pi\right)\right\}
$$

The optimal contract simply specifies the proper $f$ in (2.4) to alleviate the inflationary bias; taking the first order condition and solving as above for both types of Phillips curves, the 
optimal f equals -aw $\Upsilon{ }^{4}$

\section{Price Level and Inflation Targeting}

While the previous section makes clear that many of the standard results on monetary policy discretion derived with Neoclassical Phillips curves hold in a New-Keynesian Phillips curve framework, the two Phillips curves have different implications for the impact of price level and inflation target procedures on economic performance. The monetary policy derived in section 2 assumes that the monetary authority targets inflation and output. As is clear from (2.3), inflation targeting imparts a unit root to the price level (i.e., base drift) for both Phillips curves. A long line of work, including Wicksell (1936), Fisher (1945), Simons (1948), Mints (1950), and recently Svensson (1996), notes that this unit root imparts a great deal of uncertainty to planning over medium to long horizons, and therefore some price level target, which generates a trend stationary price level path, may be a better goal for monetary policy. This section pursues the implications of this thought, which takes on practical importance given the prominence debates over inflation and price level targeting have played in recent policy discussions by economists from the central banks of Australia, Canada, England, Finland, Israel, New Zealand, Spain, and Sweden. ${ }^{5}$

Imagine the central bank is directed to target the price level, so its loss function is given by

$$
\mathrm{L}=\sum_{\mathrm{i} \geq 0} \beta^{\mathrm{i}} \mathrm{E}_{\mathrm{t}}\left\{\left(\mathrm{p}_{\mathrm{t}+\mathrm{i}}-\Phi_{\mathrm{t}+\mathrm{i}}\right)^{2}+\mathrm{w}\left(\mathrm{y}_{\mathrm{t}+\mathrm{i}}-\Upsilon\right)^{2}\right\}
$$

\footnotetext{
${ }^{4}$ For the theorist, Walsh-type inflation contracts are a nice cure to the inflationary bias. Practical implementation of these inflation contracts may prove more difficult (see Svensson (1997)).

5 This list corresponds to participants at the Bank of England's conference on inflation targets (see the volume containing Haldane and Salmon (1995)); the issue is also discussed in the Bank of Canada volume containing Fillion and Tetlow (1994).
} 


$$
\Phi_{\mathrm{t}+\mathrm{i}}=\pi \mathrm{i}, \mathrm{i} \geq 0
$$

where $\Phi_{t+i}$ is the price level target in period $t+i$, which grows at rate $\pi$ so that the desired level of inflation under both price level and inflation targeting is identical. ${ }^{6}$

In considering price level targeting, it will prove useful to express the Phillips curves in terms of price levels:

Neoclassical: $\quad \mathrm{y}_{\mathrm{t}}=\mathrm{a}\left(\mathrm{p}_{\mathrm{t}}-\mathrm{E}_{\mathrm{t}-1} \mathrm{p}_{\mathrm{t}}\right)+\mathrm{e}_{\mathrm{t}}$,

New-Keynesian: $\quad \mathrm{y}_{\mathrm{t}}=\mathrm{a}\left(2 \mathrm{p}_{\mathrm{t}}-\mathrm{p}_{\mathrm{t}-1}-\mathrm{E}_{\mathrm{t}} \mathrm{p}_{\mathrm{t}+1}\right)+\mathrm{e}_{\mathrm{t}}$.

Inspection of (3.3) and (3.1), and (2.1) and (1.6), reveals that the price level targeting monetary policy will be very similar to the inflation targeting monetary policy for the Neoclassical Phillips curve:

Neoclassical: $\quad \mathrm{p}_{\mathrm{t}+\mathrm{i}}=\pi \mathrm{i}+\mathrm{aw} \Upsilon-\left(\mathrm{aw} /\left(1+\mathrm{a}^{2} \mathrm{w}\right)\right) \mathrm{e}_{\mathrm{t}}$

Two important points arise for Neoclassical Phillips curves and price level targeting. First, price level targeting results in a price level bias, but no inflation bias, as the average inflation rate under (3.5) is $\pi$. Second, price level targeting generates no extra output variability from the inflation targeting case, as inspection of $(1.6,2.3 \mathrm{a}$ and $3.3,3.5)$ reveals that only the price level surprise at period t matters for output movements under a Neoclassical Phillips curve, and the price level surprise at time $t$ is identical under price level and inflation targeting (because the t-1 price level is known at time t-1). These results underlie Svensson's (1996) claim that price level targeting is a free lunch involving lower long run price level uncertainty, and no increased output variability. This free lunch is a direct contradiction of

\footnotetext{
${ }^{6}$ While beyond the scope of this paper, several arguments have been made for a positive average rate of inflation, including downward nominal wage rigidity (see Akerlof, Dickens, and Perry (1996)) and the nonnengativity constraint on nominal interest rates (see Summers (1991)).
} 
the conventional wisdom from simulations of small macroeconomic models; these models typically imply that price level targeting raises output variability (Lebow, Roberts, and Stockton (1992), Fillion and Tetlow (1994), and Haldane and Salmon (1995)). The "free lunch" arises under a Neoclassical Phillips curve because (3.3) and (1.6) both imply (for independently distributed e) that $\mathrm{E}_{\mathrm{t}-1} \mathrm{y}_{\mathrm{t}}=0$, so that the targeting regime (inflation or price level) has no effect on expected output fluctuations.

This Neoclassical Phillips curve result on price level targeting and expected output variability contradict the conventional wisdom because most small scale macroeconomic models are based on structures (staggered price setting) that imply a New-Keynesian Phillips curve. To examine price level targeting under the New-Keynesian Phillips curve, note that output fluctuations in (3.4) depend on the lagged price level, so that the minimization of (3.1) will need to take into account this state variable. The optimal price level target policy therefore involves minimization of the following value function (V) with respect to the price level, with the Phillips curve (3.4) as a constraint:

$$
\mathrm{V}\left(\mathrm{p}_{\mathrm{t}-1}, \mathrm{e}_{\mathrm{t}}\right)=\mathrm{E}_{\mathrm{t}} \min \left\{\left(\mathrm{p}_{\mathrm{t}+\mathrm{i}}-\Phi_{\mathrm{t}+\mathrm{i}}\right)^{2}+\mathrm{w}\left(\mathrm{y}_{\mathrm{t}+\mathrm{i}}-\Upsilon\right)^{2}+\beta \mathrm{V}\left(\mathrm{p}_{\mathrm{t}}\right)\right\}
$$

where the supply shock is also a state variable. Given the quadratic objective and linear constraint, the value function will be quadratic

$$
\mathrm{V}\left(\mathrm{p}_{\mathrm{t}-1}, \mathrm{e}_{\mathrm{t}}\right)=\mathrm{c}+\mathrm{dp} \mathrm{p}_{\mathrm{t}-1}+\mathrm{fe} \mathrm{e}_{\mathrm{t}}+\mathrm{gp}_{\mathrm{t}-1} \mathrm{e}_{\mathrm{t}}+\mathrm{hp}_{\mathrm{t}-1}{ }^{2}+\mathrm{ie}_{\mathrm{t}}^{2}
$$

Finally, as the focus within the New-Keynesian Phillips curve analysis is the implications of price level targeting for output variability, I will set the target inflation rate and output level to zero; this simply serves to eliminate constants below.

The first order condition for the price level under the New-Keynesian Phillips curve is 
then

$$
p_{t}+\beta d / 2+\beta h p_{t}=-2 a w y_{t}
$$

Guessing that the solution for the price level contains a constant, the lagged price level, and the Phillips curve shock (e), and inserting (3.4) into (3.8) yields the following solution for the price level:

$$
\mathrm{p}_{\mathrm{t}}=\mathrm{b}_{1} \mathrm{p}_{\mathrm{t}-1}+\mathrm{b}_{2} \mathrm{e}_{\mathrm{t}}, 0<\mathrm{b}_{1}<1.7
$$

Substituting (3.9) into (3.4) reveals that $\mathrm{E}_{\mathrm{t}-1} \mathrm{y}_{\mathrm{t}}=-\mathrm{a}\left(1-\mathrm{b}_{1}\right)^{2} \mathrm{p}_{\mathrm{t}-1}$ under price level targeting and a New-Keynesian Phillips curve. In contrast, $\mathrm{E}_{\mathrm{t}-1} \mathrm{y}_{\mathrm{t}}=0$ under inflation targeting and a NewKeynesian Phillips curve $((2.3 b)$ in $(1.11))$. Price level targeting leads to more expected movements in output relative to the degree of expected output movement under inflation targeting. This result is intuitive. With the sticky price foundations of the New-Keynesian Phillips curve, anticipated price level movements lead to output fluctuations. Because price level targeting requires expected deflations after an unexpected inflation, price level targeting under a New-Keynesian Phillips curve induces variation in expected output. ${ }^{8}$ This result confirms the findings of simulations from small-scale macroeconomic models and identifies the source of disagreement in Svensson (1996); Svensson's analysis does not use a model of

\footnotetext{
${ }^{7} \mathrm{~h}, \mathrm{~b}_{1}$, and $\mathrm{b}_{2}$ solve the following equations: $\left(1+\beta h+4 a^{2} w\right) b_{1}=2 a^{2} w+2 a^{2} w_{1}^{2},\left(1+\beta h-2 a^{2} w b_{1}+4 a^{2} w\right) b_{2}=-2 a w$,
} and a third equation for $\mathrm{h}$ determined by substituting (3.9) into (3.6) and equating coefficients on $\mathrm{p}_{\mathrm{t}-1}{ }^{2}$. I have been unable to find the closed form solutions for these parameters. The first equation above, and stability, imply $0<b_{1}<1$.

${ }^{8}$ The focus herein is on reconciling conventional wisdom regarding price level targeting and output variability with analytic results from the literature on discretionary monetary policy. Another implication explored in Svensson (1996) is the idea that price level targeting may not only lower the variance of the price level, but may also lower the variance of inflation because price level targeting links the price level and output (equation (3.8)), implying that the variance of inflation is related to the variance of the change in output. If output is very persistent, the change in output has a low variance, implying a low variance for inflation. 
gradual price adjustment like the New-Keynesian model. In addition, the result may raise additional issues about the practicality or desirability of price level targeting. For example, price level targeting implies that the monetary authority is expected to cause a recession following an unanticipated inflation, and such a move may prove difficult to implement for political economy reasons.

\section{Conclusion}

Models of monetary policy emphasizing discretion have proved useful in analyzing inflation performance and monetary institutions. This paper has illustrated that many of the standard results in this literature are implications of both the Neoclassical Phillips curve (the standard in the literature), and the recently discussed New-Keynesian Phillips curve. However, these Phillips curves rest on quite different foundations, and differ in their implications for expected output variability under price level targeting and inflation targeting. In particular, the New-Keynesian Phillips curve confirms the results from simulations of small scale macroeconomic models that price level targeting leads to expected recessions from the deflations following surprise inflations, and hence increases expected output movements relative to inflation targeting. This result is unsurprising given that small scale macroeconomic models are built on foundations implying a New-Keynesian Phillips curve, but is important given recent attempts to expand the implications of Neoclassical Phillips curve models. Future research on discretionary monetary policy would benefit from considering the New-Keynesian Phillips curve. 


\section{References}

Akerlof, G., Dickens, W. and Perry, G. (1996) The Macroeconomics of Low Inflation. Brookings Papers on Economic Activity 1:1-59.

Alesina, A. (1987) Macroeconomic Policy in a Two Party System as a Repeated Game. Quarterly Journal of Economics 102:651-78.

Barro, R. and Gordon, D. (1983) Rules, Discretion, and Reputation in a Model of Monetary Policy. Journal of Political Economy 12:101-122.

Barro, R. and Grossman, H. (1976) Money, Employment, and Inflation. Cambridge University Press.

Blanchard, O.J. (1990) Why Does Money Affect Output? A Survey. In Hahn, F. and B. Friedman, eds. Handbook of Monetary Economics. North Holland Publishers.

Brayton, F. and P. Tinsley (1996) A Guide to FRB/US: A Macroeconomic Model of the United States. Federal Reserve Board FEDS Working Paper 1996-42.

Calvo, G.A. (1983) Staggered Prices in a Utility Maximizing Framework. Journal of Monetary Economics 12:383-398.

Fillion, J.F. and Tetlow, R. (1994) Can Inflation Serve as a Market Lubricant? In Bank of Canada (1994) Economic Behavior and Policy Choice Under Price Stability. 129-166.

Fischer, S. (1977) Long Term Contracts, Rational Expectations, and the Optimal Money Supply Rule. Journal of Political Economy 85:191-205.

Fischer, S. (1994) Modern Central Banking. In Capie, F. et al. The Future of Central Banking. Cambridge University Press.

Fisher, I. (1945) 100\% Money. City Printing Company.

Haldane, A.G. and Salmon, C.K. (1995) Three Issues on Inflation Targets. In Haldane, A., ed. Targeting Inflation. Bank of England. 170-201.

Lebow, D.E., Roberts, J.M. and Stockton, D.J. (1992) Economic Performance under Price Stability. Federal Reserve Board Division of Research and Statistics Working Paper \# 125.

Lucas, R.E. Jr. (1973) Some International Evidence on Output Inflation Tradeoffs. American Economic Review 63:326-34.

McCallum, B.T. (1994) A Semi-Classical Model of Price Level Adjustment. Carnegie- 
Rochester Conference Series on Public Policy 41:251-84.

Mints (1950) Monetary Policy for a Competitive Society. McGraw Hill.

Mussa, M. (1981a) Sticky Individual Prices and the Dynamics of the General Price Level. Carnegie-Rochester Conference Series on Public Policy 15:261-96.

Mussa, M. (1981b) Sticky Prices and Disequilibrium Adjustment in a Rational Model of the Inflationary Process. American Economic Review 71:1020-1027.

Roberts, J. (1995) New-Keynesian Economics and the Phillips Curve. Journal of Money, Credit, and Banking 27:975-984.

Rogoff, K. (1985) The Optimal Degree of Commitment to a Monetary Target. Quarterly Journal of Economics 100:1169-90.

Rotemberg, J.J. (1982) Sticky Prices in the United States. Journal of Political Economy 90:1187-211.

Rotemberg, J.J. (1987) The New Keynesian Microfoundations. NBER Macroeconomics Anпиаl 1987 69-104.

Rotemberg, J.J. (1996) Prices, Output, and Hours: An Empirical Analysis Based on a Sticky Price Model. Journal of Monetary Economics 37:505-533.

Schaling, E. (1995) Institutions and Monetary Policy. Edward Elgar Publishing Co.

Simons, H. (1948) Economic Policy for a Free Society. University of Chicago Press.

Summers, L. (1991) How Should Long-Term Monetary Policy Be Determined? Journal of Money, Credit, and Banking 23:625-31.

Svensson, L. (1996) Price Level Targeting vs. Inflation Targeting: A Free Lunch? NBER Working Paper \#5719.

Svensson, L. (1997) Optimal Inflation Targets, 'Conservative Central Banks', and Linear Inflation Contracts. American Economic Review 87:98-114.

Taylor, J.B. (1980) Aggregate Dynamics and Staggered Contracts. Journal of Political Economy. 88:1-23.

Walsh, C.E. (1995) Optimal Contracts for Central Bankers. American Economic Review $85: 150-167$. 